\title{
A rare mimic of contained cardiac rupture: a diagnostic and therapeutic dilemma at a crucial time
}

\author{
Pritesh Parekh, Apurva Vasavada, Navin Agrawal, Mahesh Vinchurkar
}

Department of Cardiology, Care Hospital, Surat, Gujarat, India

\section{Correspondence to} Dr Navin Agrawal, drnavinagrawal@gmail.com

\section{DESCRIPTION}

We present an interesting case of an elderly woman without diabetes, hypertension and dyslipidaemia, who presented to us with an evolved inferoposterior wall infarction and developed ventricular fibrillation and hypotension immediately after admission (figure 1). An emergency echocardiogram revealed a large collection in the pericardium which was thick and echolucent in consistency suggestive of clotted blood and was initially diagnosed as a contained cardiac rupture which was the most plausible diagnosis considering the circumstances of the clinical presentation. Although the exact site of rupture into the pericardium could not be located (videos 1-4 and figure 2). There was no echocardiographic right ventricle collapse suggestive of pericardial tamponade despite the large collection and tachycardia. Pericardiocentesis was not attempted as the patient was not in tamponade and chances of rebleed into the pericardial space were high. The anticoagulants were withheld and supportive treatment was given keeping surgical standby.

The angiogram revealed double-vessel disease but the presence of a suspected 'rupture' made it difficult

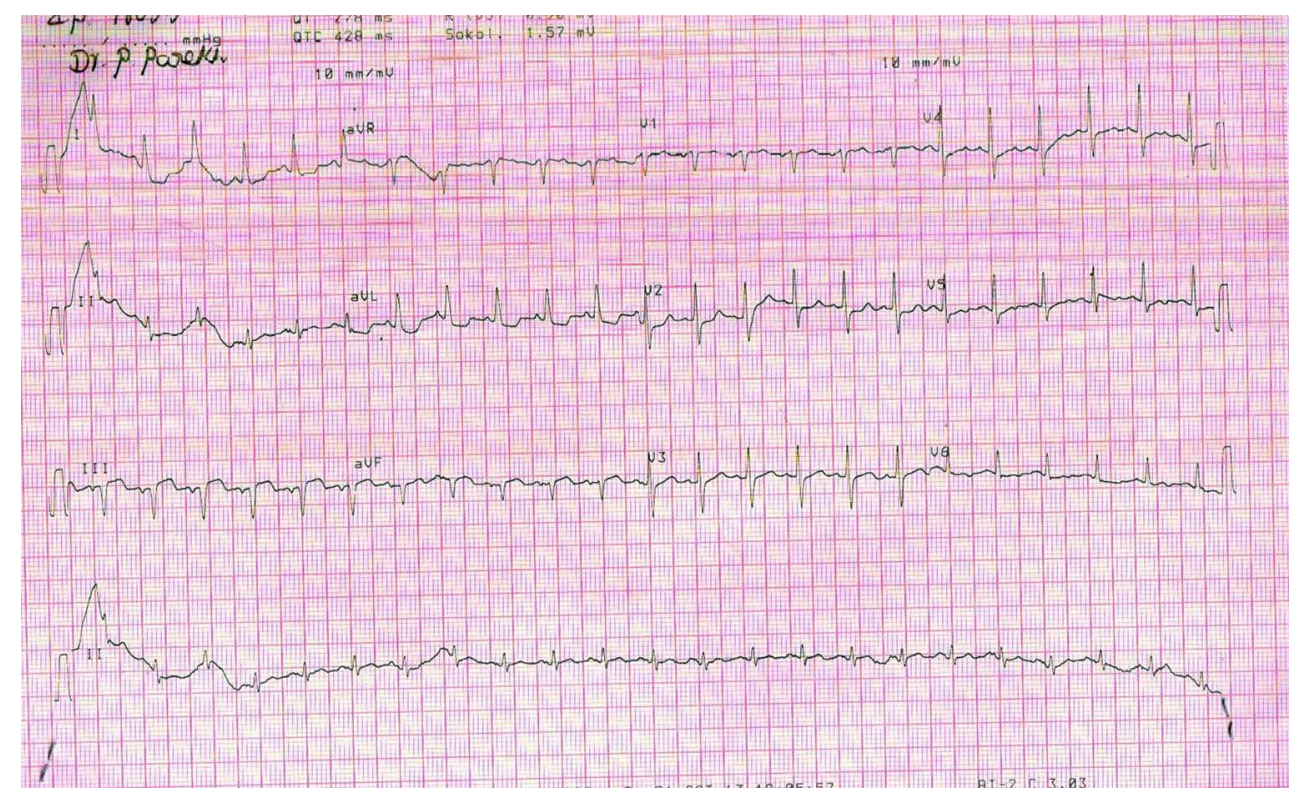

Figure 1 ECG of the patient showing evolved inferior wall myocardial infarction with sinus tachycardia.

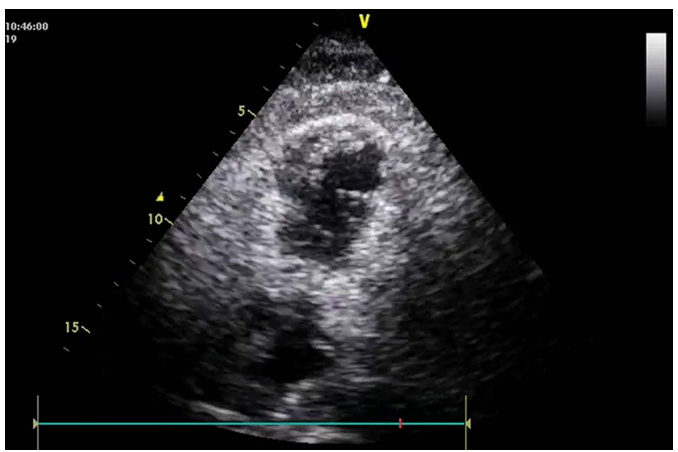

Video 1 Modified apical four chambered view showing a thick pericardial collection which was initially as confused to be a contained cardiac rupture with clotted blood.

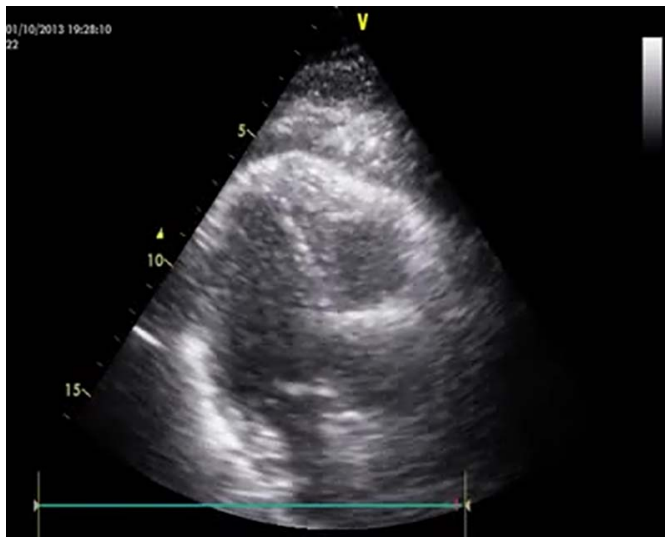

Video 2 Modified apical four chambered view showing a thick layer of pericardial fat. 


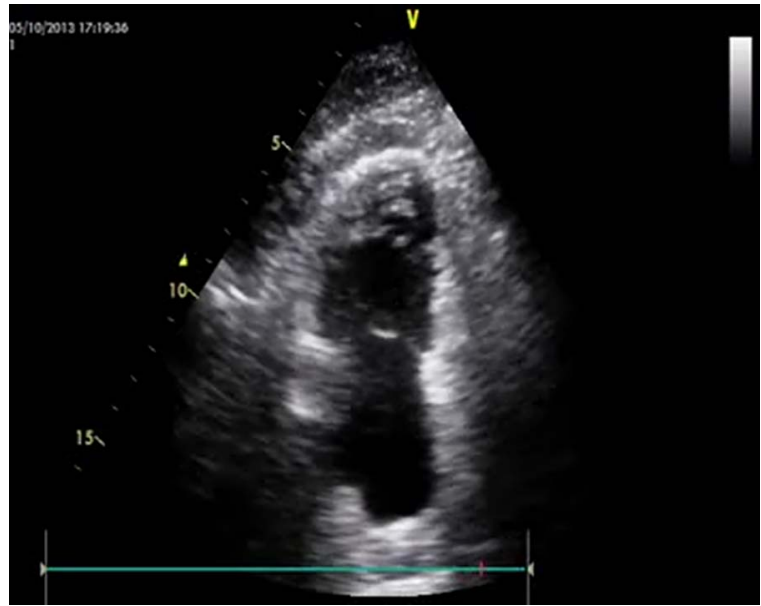

Video 3 Modified apical two chambered view showing thick pericardial layer of fat.

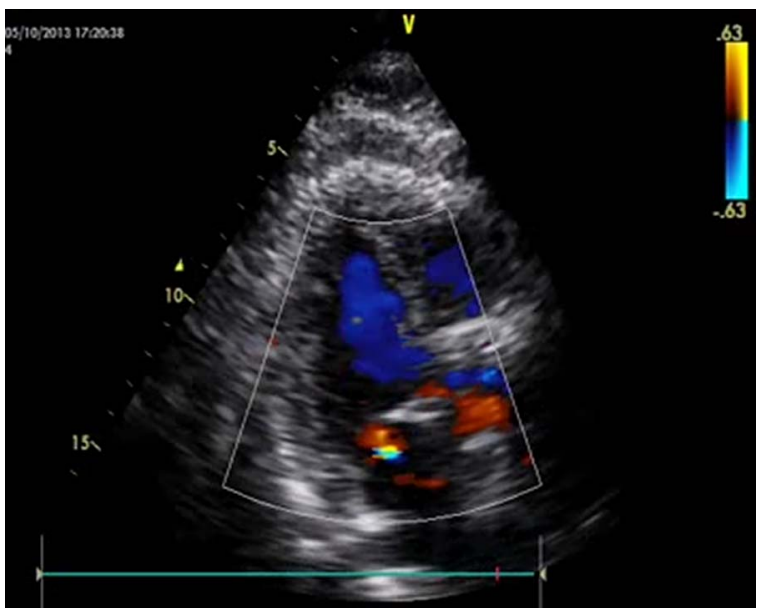

Video 4 Modified apical four chambered view showing pericardial fat and proving the absence of severe valvular lesions.

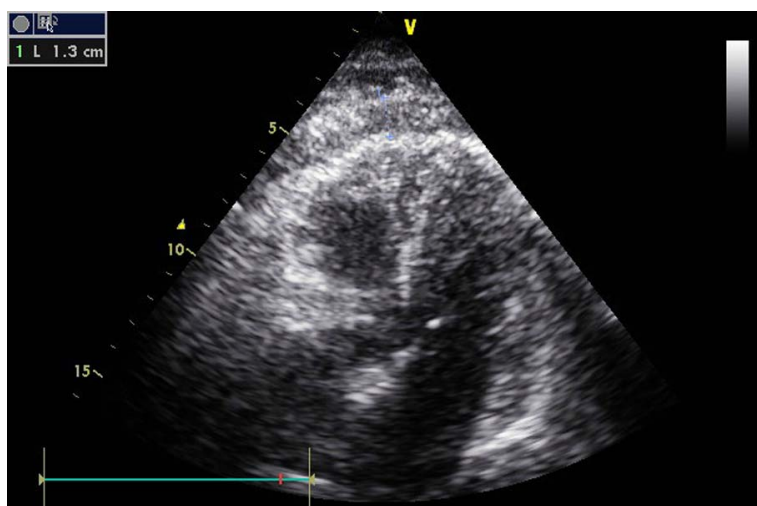

Figure 2 A still image of the echocardiogram in four-chambered view showing a large pericardial collection around the heart.

to take the patient for percutaneous intervention (PCI) given the risk of rebleeding due to anticoagulants and high-dose antiplatelets during and after PCI. Fluoroscopy revealed a translucent layer of tissue around the heart unlike that expected in tamponade (videos 5-6). The X-ray showed duplicated cardiac border (figure 3). After fluoroscopy and after comparison with the initially unavailable old

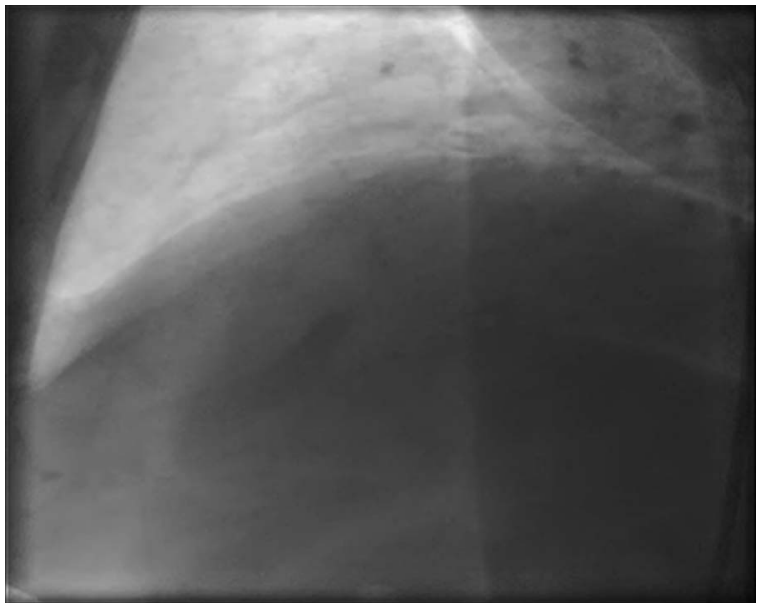

Video 5 An angiographic film taken during the angiography showing the translucent shadow around the heart.

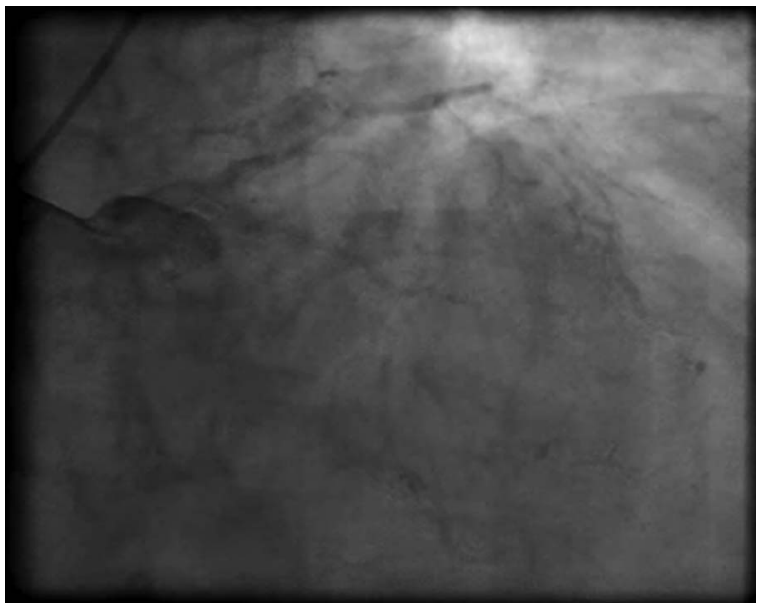

Video 6 Another fluoroscopic image of the heart showing the translucent shadow around the heart.

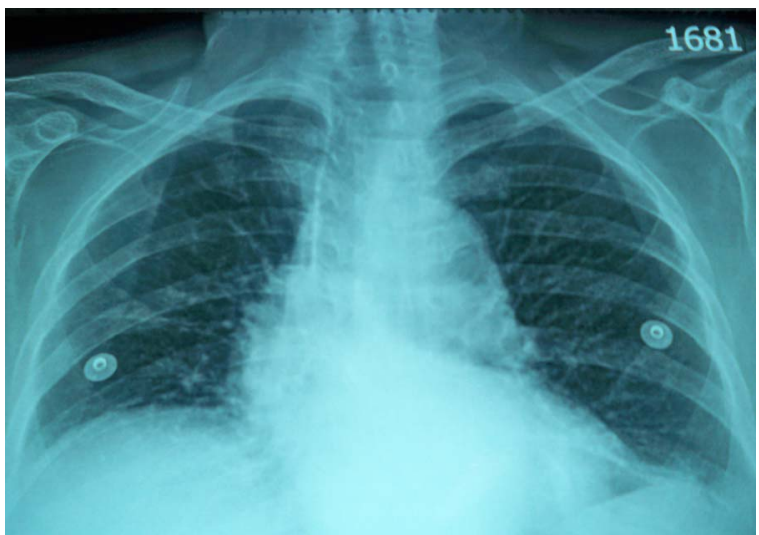

Figure 3 X-ray of the patient showing double cardiac shadow which is better seen around the right atrial margin.

echocardiograms in which the size and consistency of 'the collection' appeared constant, we concluded that probably an unusually thick layer of pericardial fat was mimicking pericardial collection. ${ }^{1-3}$ The patient subsequently underwent successful PCI with stent implantation to the right coronary artery and the clinical parameters improved with medical management. 


\section{Learning points}

- Pericardial fat can sometimes be extraordinarily thick even in a non-diabetic and non-dyslipidemic patient with which it is more commonly associated ${ }^{3}$ and can produce a confusing echocardiographic mimic of pericardial effusion.

- A previously undiagnosed presence of pericardial fat can mimic a contained cardiac rupture and in a patient with myocardial infarction they can pose a diagnostic and therapeutic dilemma which could dramatically alter the treatment strategies as happened in this case.

- Serial echocardiograms, fluoroscopy, comparison of old records and circumstantial evidence from the clinical presentation can form the key to the correct diagnosis and appropriate management.
Competing interests None.

Patient consent Obtained.

Provenance and peer review Not commissioned; externally peer reviewed.

\section{REFERENCES}

1 Sacks HS, Fain JN. Human epicardial adipose tissue: a review. Am Heart J 2007;153:907-17.

2 Sarin S, Wenger C, Marwaha A, et al. Clinical significance of epicardial fat measured using cardiac multislice computed tomography. Am J Cardiol 2008;102:767-71.

3 Fox CS, Massaro JM, Hoffmann U, et al. Abdominal visceral and subcutaneous adipose tissue compartments: association with metabolic risk factors in the Framingham Heart Study. Circulation 2007;116:39-48.

Copyright 2013 BMJ Publishing Group. All rights reserved. For permission to reuse any of this content visit http://group.bmj.com/group/rights-licensing/permissions.

BMJ Case Report Fellows may re-use this article for personal use and teaching without any further permission.

Become a Fellow of BMJ Case Reports today and you can:

- Submit as many cases as you like

- Enjoy fast sympathetic peer review and rapid publication of accepted articles

- Access all the published articles

- Re-use any of the published material for personal use and teaching without further permission

For information on Institutional Fellowships contact consortiasales@bmjgroup.com

Visit casereports.bmj.com for more articles like this and to become a Fellow 